\title{
Effects of $1 \alpha$-hydroxylated metabolites of cholecalciferol on intestinal radiocalcium absorption in goats
}

\author{
BY KNUT HOVE \\ Department of Animal Nutrition, Agricultural University of Norway, \\ 1432 As-NLH, Norway
}

(Received 9 February 1983 -Accepted 19 July 1983)

1. Intestinal absorption of ${ }^{47} \mathrm{Ca}$ was measured by a double-isotope technique in goats treated with 1,5 or $25 \mu \mathrm{g}$ of 1,25-dihydroxycholecalciferol $\left(1,25(\mathrm{OH})_{2} \mathrm{D}_{3}\right)$. The effects of giving $1,25(\mathrm{OH})_{2} \mathrm{D}_{3}$ by intravenous (iv) infusion for $30-36 \mathrm{~h}$ were compared at each dose level with the effects obtained by oral administration of $1,25(\mathrm{OH})_{2} \mathrm{D}_{3}$ either in ethanol or protected against rumen degradation in fatty acid pellets.

2. Dose-dependent increments in absorption followed the treatments, with a doubling of absorption at the $\mathrm{l} \mu \mathrm{g}$ dose and three- to fivefold increases with the 5 and $25 \mu \mathrm{g}$ doses. ${ }^{77} \mathrm{Ca}$ absorption was equally stimulated 2 and $6 \mathrm{~d}$ after treatment but had returned to pretreatment levels $12-14 \mathrm{~d}$ after treatment.

3. Intravenous and protected oral administration of $1,25(\mathrm{OH})_{2} \mathrm{D}_{3}$ stimulated ${ }^{47} \mathrm{Ca}$ absorption to the same extent, in spite of two- to fivefold higher plasma concentrations of $1,25(\mathrm{OH})_{2} \mathrm{D}_{3}$ after iv treatment. Somewhat lower increments in ${ }^{47} \mathrm{Ca}$ absorption were seen using ethanol as the vehicle for oral administration.

4. The naturally occurring metabolites $1,24(\mathbf{R}), 25$-trihydroxycholecalciferol and 1,25(S),26-trihydroxycholecalciferol had only one-tenth to one-fifteenth the potency of $1,25(\mathrm{OH})_{2} \mathrm{D}_{3}$ in stimulating ${ }^{47} \mathrm{Ca}$ absorption, while synthetic $1 \alpha$-hydroxycholecalciferol appeared to be twice as effective as $1,25(\mathrm{OH})_{2} \mathrm{D}_{3}$ when tested at a high $(10 \mu \mathrm{g})$ dose.

Adaptation of intestinal calcium absorption has long since been recognized as an integral part of Ca homeostasis (Nicolaysen et al. 1953). Such adaptations are vitamin D dependent and mediated by changes in the renal production of 1,25-dihydroxycholecalciferol $\left(1,25(\mathrm{OH})_{2} \mathrm{D}_{3}\right) \cdot 1,25(\mathrm{OH})_{2} \mathrm{D}_{3}$ is thought to be the most active metabolite of cholecalciferol and acts as a regulating endocrine signal for intestinal Ca transport (Holick et al. 1971; Norman et al. 1971; Omdahl et al. 1971).

In most mammals studied, changes in $\mathrm{Ca}$ absorption can be detected shortly after exogenous administration of $1,25(\mathrm{OH})_{2} \mathrm{D}_{3}$. Information from ruminants on the effects of this steroid hormone on Ca absorption seems to be lacking. Abdel-Hafeez et al. (1982) reported increased absorption of $\mathrm{Ca}$ in a sheep $24-48 \mathrm{~h}$ after perfusion of an isolated segment of intestine with $1 \alpha$-hydroxycholecalciferol $\left(1(\mathrm{OH}) \mathrm{D}_{3}\right)$. Hove (1984) found the double-isotope technique for measurement of intestinal radiocalcium absorption useful for studies of rapid changes in $\mathrm{Ca}$ absorption in goats. In the present study, this technique was used to compare the effects of various doses and methods of administration of $1,25(\mathrm{OH})_{2} \mathrm{D}_{3}$. The activities of $1(\mathrm{OH}) \mathrm{D}_{3}$ and two naturally occurring trihydroxylated metabolites of cholecalciferol in promoting $\mathrm{Ca}$ absorption were also measured.

Cholecalciferol appears to be sensitive to rumen degradation when incubated with rumen liquid in an unprotected form (Sommerfeldt et al. 1980). The extent to which this also applies to metabolites of cholecalciferol is unknown. Consequently, the benefits obtained by protecting $1,25(\mathrm{OH})_{2} \mathrm{D}_{3}$ against rumen degradation during experiments on oral milk fever prophylaxis (Hove \& Kristiansen, 1982) could be questioned. A comparison of the effects of oral administration of $1,25(\mathrm{OH})_{2} \mathrm{D}_{3}$ incorporated in fatty acid pellets (protected) or given in ethanol (unprotected) was therefore included in the present study. 


\section{EX PER I MENTAL}

\section{Animals and diet}

Six female goats aged 2-5 years were used for the studies, which lasted for approximately 1 year. Abomasal cannulas were inserted by standard surgical procedures 1 month before measurements were started. The goats were kept in metabolism cages except for a grazing period of about 3 months. A basal low-Ca diet consisting of (g/d): barley 300, hay 200, extracted soya-bean meal $25, \mathrm{Ca} 0.7$ and phosphorus 1.6 was given and supplied sufficient protein and energy for maintenance. Sodium chloride and a micromineral-vitamin mixture, providing approximately $1 \mu \mathrm{g}$ cholecalciferol, were given daily. In preparation for measurements of radiocalcium absorption, animals were given extra $\mathrm{Ca}(4 \mathrm{~g} / \mathrm{d})$ as calcium acetate in the drinking-water or as an abomasal infusion. The supplementation usually lasted for $10 \mathrm{~d}$ before $\mathrm{Ca}$ absorption studies were carried out in order to obtain a low initial rate of $\mathrm{Ca}$ absorption before administration of the metabolites of cholecalciferol. Abomasal infusions were given for the last $48 \mathrm{~h}$ of this $10 \mathrm{~d}$ period and discontinued $4 \mathrm{~h}$ before the oral tracer was given. $\mathrm{Ca}$ supplements were not given until 2 weeks after treatment which resulted in highly active absorption of $\mathrm{Ca}$, in order to reduce the risk of serious hypercalcaemia. Details of the procedures for the measurements of radiocalcium absorption and calculation of the results were given earlier (Hove, 1984).

\section{Treatments with metabolites of cholecalciferol}

Synthetic 1,25(OH) $)_{2} \mathrm{D}_{3}$ (lot no. 7975-119), 1,24(R),25-trihydroxycholecalciferol (1,24(R),25( $\mathrm{OH})_{3} \mathrm{D}_{3}$, lot no. 7978-102) and 1,25(S),26-trihydroxycholecalciferol (1,25(S),26(OH) ${ }_{3} \mathrm{D}_{3}$, lot no. 8625-128) were obtained from Hoffman la Roche Inc, Nutley New Jersey, and $1 \alpha$-hydroxycholecalciferol was obtained from Leo Pharmaceuticals, Copenhagen, Denmark. Three methods of administration of $1,25(\mathrm{OH})_{2} \mathrm{D}_{3}$ were compared. Intravenous (iv) administration was given as a $30-36 \mathrm{~h}$ continuous infusion $(1.2 \mathrm{ml} / \mathrm{h})$ of a solution of the metabolite in ethanol $(500 \mathrm{ml} / \mathrm{l})$. The metabolite for oral administration was either given unprotected against rumen degradation (dissolved in $10 \mathrm{ml}$ ethanol) or protected (incorporated in fatty acid pellets designed for rumen bypass; Rumen Kjemi, A/S, Oslo). The fatty acid pellets contained $10 \mu \mathrm{g} 1,25(\mathrm{OH})_{2} \mathrm{D}_{3} / \mathrm{g}$ and the average pellet size was $40 \mathrm{mg}$. The matrix consisted of $(\mathrm{g} / \mathrm{kg}): 540 \mathrm{C}_{16}-\mathrm{C}_{20}$ fatty acids, 370 glucose, 60 calcium carbonate, 30 adjuvants (emulgator, antioxidant). The actual extent of protection against rumen degradation obtained for $1,25(\mathrm{OH})_{2} \mathrm{D}_{3}$ was not tested, but fatty acid pellets give a $70-80 \%$ bypass of amino acids and probably an even higher extent of bypass of fat-soluble vitamins. The effects of $1,25(\mathrm{OH})_{2} \mathrm{D}_{3}$ were studied at dose levels of 1,5 and $25 \mu \mathrm{g}$. At least four experiments were performed with each dose level and each method of administration, except for the $1 \mu \mathrm{g}$ dose where the protected metabolite was not given.

Measurements of radiocalcium absorption were done immediately before administration of metabolite and 2, 6 and, in several experiments, 12-14 d later. Additional studies of the effects of daily repeated doses of $5 \mu \mathrm{g}$ protected $1,25(\mathrm{OH})_{2} \mathrm{D}_{3}$ were carried out in three animals. Measurements were undertaken after a daily dose of $5 \mu \mathrm{g}$ for $2 \mathrm{~d}(10 \mu \mathrm{g}$ total) and after a daily dose of $5 \mu \mathrm{g}$ for $5 \mathrm{~d}\left(25 \mu \mathrm{g}\right.$ total). The effects of $10 \mu \mathrm{g} 1(\mathrm{OH}) \mathrm{D}_{3}$ were studied $2 \mathrm{~d}$ after iv and oral (unprotected) administration (three goats per treatment). The effects of $50 \mu \mathrm{g}$ of each of the two trihydroxylated metabolites were studied $2 \mathrm{~d}$ after iv administration (two goats per treatment).

\section{Measurements of $1,25(\mathrm{OH})_{2} \mathrm{D}_{3}$ in plasma}

$1,25(\mathrm{OH})_{2} \mathrm{D}_{3}$ was extracted from plasma by diethyl ether. The extracts were purified by open column silica chromatography and by high-pressure liquid chromatography (Aksnes, 1980) 
on a silica column (Chrompack Partisil, $5 \mu$ particles; Chrompack, Middelburg, The Netherlands). The metabolite was quantified by a radioimmunoassay (Clemens et al. 1979) using standard $1,25(\mathrm{OH})_{2} \mathrm{D}_{3}$, sheep anti-1,25(OH) ${ }_{2} \mathrm{D}_{3}$ antibody (Sheep 02282) and $\left[{ }^{3} \mathrm{H}\right] 1,25(\mathrm{OH})_{2} \mathrm{D}_{3}$ (about $90 \mathrm{Ci} / \mathrm{mmol}$ ).

\section{RESULTS}

Treatments with $1,25(\mathrm{OH})_{2} D_{3}$

The mean radiocalcium absorption for all goats measured just before $1,25(\mathrm{OH})_{2} \mathrm{D}_{3}$ treatment (day 0 ) was 15 (SD 7) \% of the administered dose. Absolute values for day 0 , and for days 2, 6 and 12-14 after treatment are given in Figs. 1 and 2. All treatments resulted in increased radiocalcium absorption on day 2 and about the same level of absorption was found $4 \mathrm{~d}$ later irrespective of dose or type of administration (Figs. 1 and 2). The stimulation of radiocalcium absorption by $1,25(\mathrm{OH})_{2} \mathrm{D}_{3}$ resulted in doubling of the initial values with the $1 \mu \mathrm{g}$ dose and up to two- to fourfold the initial values at the highest dose given (Figs. 1 and 2).

Radiocalcium absorptions $12-14 \mathrm{~d}$ after treatment were close to the values obtained at day 0 for both the 1 and $5 \mu \mathrm{g}$ doses (Fig. 1).

Increments in radiocalcium absorption were calculated in order to compare doses and types of administration of $1,25(\mathrm{OH})_{2} \mathrm{D}_{3}$, since significant differences in the rate of absorption between individual goats were detected at day 0 . The increments were linearly

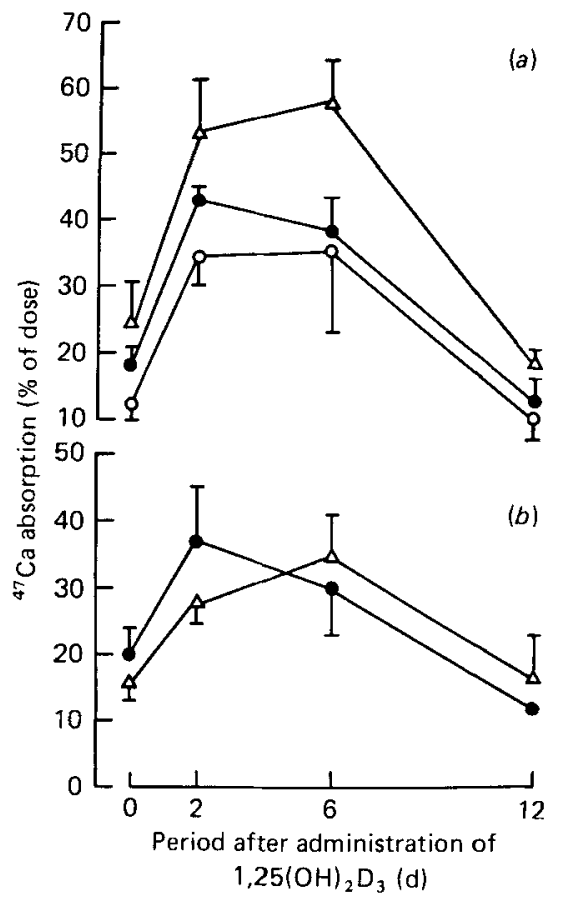

Fig. 1. Absorption of ${ }^{47} \mathrm{Ca}(\%$ of dose) measured in goats before and 2,6 and $12 \mathrm{~d}$ after treatment with (a) $5 \mu \mathrm{g} 1,25$-dihydroxycholecalciferol $\left(1,25(\mathrm{OH})_{2} \mathrm{D}_{3}\right)$ and $(b) 1 \mu \mathrm{g} 1,25(\mathrm{OH})_{2} \mathrm{D}_{3}$. Mean values, with their standard errors represented by vertical bars, for three to five animals per treatment. $1,25(\mathrm{OH})_{2} \mathrm{D}_{3}$ given intravenously $(\triangle)$, or orally, dissolved in ethanol $(O)$ or in pellets of fatty acids $(\bullet)$. 


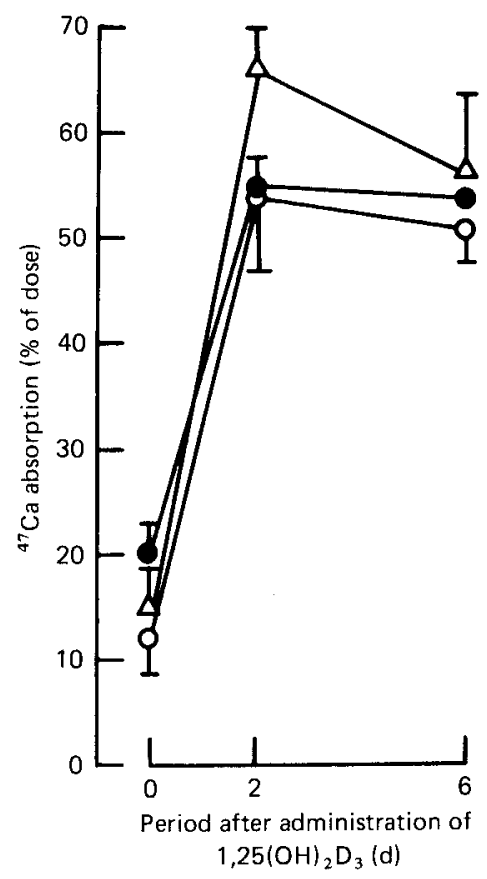

Fig. 2. Absorption of ${ }^{47} \mathrm{Ca}(\%$ of dose) measured in goats before and 2 and $6 \mathrm{~d}$ after treatment with $25 \mu \mathrm{g}$ 1,25-dihydroxycholecalciferol $\left(1,25(\mathrm{OH})_{2} \mathrm{D}_{3}\right)$. Mean values, with their standard errors represented by vertical bars, for four animals per treatment. $1,25(\mathrm{OH})_{2} \mathrm{D}_{3}$ given intravenously $(\triangle)$, or orally, dissolved in ethanol $(O)$ or in pellets of fatty acids $(O)$.

related to the logarithm of the administered dose (Fig. 3). Linear regression equations were calculated for increments in radiocalcium absorption $(y) v . \log _{\mathrm{e}} 1,25(\mathrm{OH})_{2} \mathrm{D}_{3}$ dose $(x)$ :

iv administration, $y=0 \cdot 10+0 \cdot 11 x$,

protected oral administration, $y=0.05+0 \cdot 11 x$,

unprotected oral administration, $y=0 \cdot 16+0.05 x$.

The corresponding regression coefficients were all different from zero $(P<0.001, P<0.01$ and $P<0.02$ respectively, $t$ test). Significant differences between coefficients were obtained for the iv and oral unprotected treatments with $1,25(\mathrm{OH})_{2} \mathrm{D}_{3}(P<0.02, t$ test), while the difference between protected and unprotected oral treatments approached significance $(0 \cdot 1>P>0.05)$. Differences between the three methods of administration were not significant when the 1 and $5 \mu \mathrm{g}$ dose levels were judged separately (Fig. 3). The difference in increments between iv and unprotected oral treatments was, however, significant at the $25 \mu \mathrm{g}$ dose level $(P<0.01, t$ test $)$.

A daily dose of $5 \mu \mathrm{g}$ protected $1,25(\mathrm{OH})_{2} \mathrm{D}_{3}$ for $5 \mathrm{~d}$ resulted in an increase in $\mathrm{Ca}$ absorption from 15.6 to $69.2 \%$ (average of three goats). This increment of $53.6 \%$ units corresponded to an increment of $42.0 \%$ units when the full dose $(25 \mu \mathrm{g})$ was given at once (Fig. 3). An increment of $38.6 \%$ units was seen when $5 \mu \mathrm{g}$ was given for two consecutive days. This increment corresponded to a dose of about $20 \mu \mathrm{g}$ protected $1,25(\mathrm{OH})_{2} \mathrm{D}_{3}$ (Fig. 3). Changes in plasma $1,25(\mathrm{OH})_{2} \mathrm{D}_{3}$ concentrations after treatments with 1,5 and $25 \mu \mathrm{g} 1,25(\mathrm{OH})_{2} \mathrm{D}_{3}$ were clearly related to the dose given both for the iv and oral treatments (Table 1). Plasma $1,25(\mathrm{OH})_{2} \mathrm{D}_{3}$ concentrations were generally two to six times 


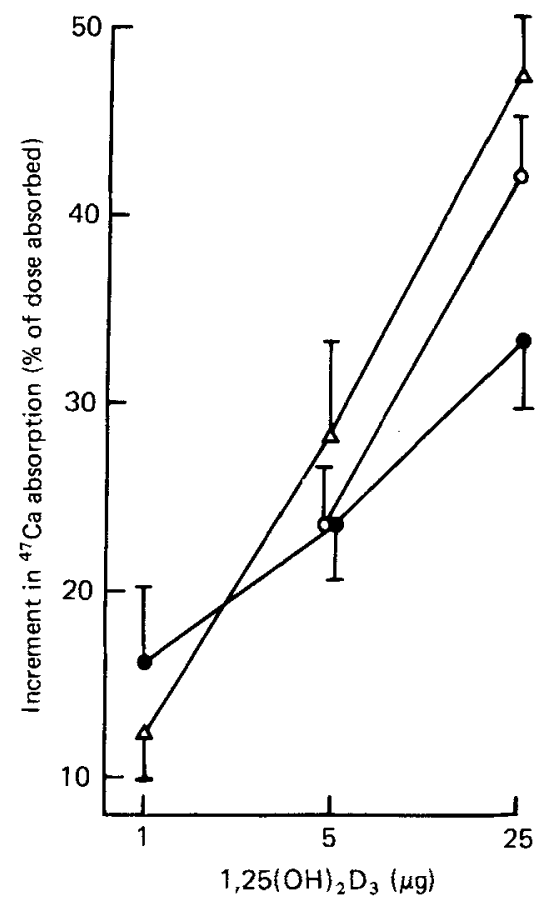

Fig. 3. Increments in ${ }^{47} \mathrm{Ca}$ absorption (mean values with their standard errors) in goats after treatments with 1,5 or $25 \mu \mathrm{g}$ of 1,25-dihydroxycholecalciferol $\left(1,25(\mathrm{OH})_{2} \mathrm{D}_{3}\right)$. Administration of the cholecalciferol metabolite by intravenous infusion for $30-36 \mathrm{~h}(\triangle)$, or orally, dissolved in ethanol $(O)$ or in pellets of fatty acids (O).

higher after iv administration than after oral administration. No clearcut differences between concentrations after treatments with oral protected and unproticted metabolites could be detected (Table 1).

Table 1. Plasma concentrations of 1,25-dihydroxyvitamin $D(\mathrm{pg} / \mathrm{ml})$ before and $2 \mathrm{~d}$ after the start of treatment with intravenous (iv), oral protected (op) and oral, unprotected (oup) doses of 1,5 and $25 \mu \mathrm{g}$ 1,25-dihydroxycholecalciferol

(Mean values with their standard errors for three to four goats per treatment)

\begin{tabular}{|c|c|c|c|c|c|}
\hline \multirow{3}{*}{$\begin{array}{l}\text { Dose } \\
(\mu \mathrm{g})\end{array}$} & \multirow{3}{*}{$\begin{array}{l}\text { Method of } \\
\text { administration }\end{array}$} & \multicolumn{4}{|c|}{ Plasma 1,25-dihydroxyvitamin $\mathrm{D}(\mathrm{pg} / \mathrm{ml})$} \\
\hline & & \multicolumn{2}{|c|}{ Before treatment } & \multicolumn{2}{|c|}{$2 \mathrm{~d}$ after treatment } \\
\hline & & Mean & SE & Mean & SE \\
\hline \multirow[t]{3}{*}{25} & iv & 53 & 7 & 554 & 25 \\
\hline & op & 58 & 7 & 184 & 13 \\
\hline & oup & 54 & 14 & 214 & 37 \\
\hline \multirow[t]{3}{*}{5} & iv & 40 & 8 & 247 & 8 \\
\hline & op & 38 & 7 & 124 & 40 \\
\hline & oup & 64 & 15 & 89 & 7 \\
\hline \multirow[t]{2}{*}{1} & iv & 49 & 5 & 89 & 4 \\
\hline & oup & 44 & 15 & 76 & 14 \\
\hline
\end{tabular}


Table 2. Effects of $1(\mathrm{OH}) D_{3}, 1,24(\mathrm{R}), 25(\mathrm{OH})_{3} D_{3}$ and $1,25(\mathrm{~S}), 26(\mathrm{OH})_{3} D_{3}$ on radiocalcium absorption in goats. The metabolites of vitamin $D_{3}$ were either given by an intravenous (iv) infusion of $30 \mathrm{~h}$ duration or orally dissolved in $10 \mathrm{ml}$ ethanol $(500 \mathrm{ml} / \mathrm{l})$. Radiocalcium absorption (\% of dose absorbed in $180 \mathrm{~min}$; mean values and ranges) was measured just before and $2 d$ after the start of treatment

\begin{tabular}{|c|c|c|c|c|c|c|c|}
\hline \multirow[b]{3}{*}{ Vitamin $D_{3}$ metabolite } & \multirow{3}{*}{$\begin{array}{l}\text { Dose } \\
(\mu \mathrm{g})\end{array}$} & \multirow{3}{*}{$\begin{array}{l}\text { Method of } \\
\text { administration }\end{array}$} & \multirow{3}{*}{$\begin{array}{l}\text { No. of } \\
\text { animals }\end{array}$} & \multicolumn{4}{|c|}{ Radiocalcium absorption } \\
\hline & & & & \multicolumn{2}{|c|}{$\begin{array}{c}\text { Before } \\
\text { treatment }\end{array}$} & \multicolumn{2}{|c|}{$\begin{array}{l}2 \mathrm{~d} \text { after } \\
\text { treatment }\end{array}$} \\
\hline & & & & Mean & Range & Mean & Range \\
\hline $1(\mathrm{OH}) \mathrm{D}_{3}$ & 10 & iv & 3 & 29 & $(26-35)$ & 75 & $(70-80)$ \\
\hline $1(\mathrm{OH}) \mathrm{D}_{3}$ & 10 & oral & 3 & 16 & $(13-18)$ & 52 & $(45-58)$ \\
\hline $1,24(\mathrm{R}), 25(\mathrm{OH})_{3} \mathrm{D}_{3}$ & 50 & iv & 2 & 14 & $(12-15)$ & 37 & $(36-39)$ \\
\hline $1,25(\mathrm{~S}), 26(\mathrm{OH})_{3} \mathrm{D}_{3}$ & 50 & iv & 2 & 20 & $(16-23)$ & 43 & $(41-46)$ \\
\hline
\end{tabular}

$1(\mathrm{OH}) \mathrm{D}_{3}=1 \alpha$-hydroxycholecalciferol; $1,24(\mathrm{R}), 25(\mathrm{OH})_{3} \mathrm{D}_{3}=1,24(\mathrm{R}), 25$-trihydroxycholecalciferol; $1,25(\mathrm{~S}), 26$ $(\mathrm{OH})_{3} \mathrm{D}_{3}=1,25(\mathrm{~S}), 26$-trihydroxycholecalciferol.

Treatments with $\mathrm{l}(\mathrm{OH}) \mathrm{D}_{3}, 1,24(\mathrm{R}), 25(\mathrm{OH})_{3} \mathrm{D}_{3}$ and $1,25(\mathrm{~S}), 26(\mathrm{OH})_{3} \mathrm{D}_{3}$ $1(\mathrm{OH}) \mathrm{D}_{3}$ and the two trihydroxylated metabolites increased radiocalcium absorption, with $1(\mathrm{OH}) \mathrm{D}_{3}$ the most potent metabolite (Table 2). Absorption increased on average $46 \%$ units after iv administration of a $10 \mu \mathrm{g}$ dose and $36 \%$ units after oral administration of unprotected $1(\mathrm{OH}) \mathrm{D}_{3}$. These increments were of the same order as increments obtained with

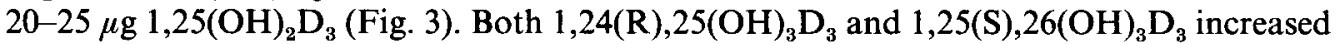
radiocalcium absorption by an average of $24 \%$ units when given intravenously in a dose of $50 \mu \mathrm{g}$ (Table 2). The potency of these two metabolites thus seemed equivalent to approximately $3-4 \mu \mathrm{g}$ of $1,25(\mathrm{OH})_{2} \mathrm{D}_{3}$ (Fig. 3).

\section{DISCUSSION}

Dose-dependent increases in radiocalcium absorption were detected after treatment with $1,25(\mathrm{OH})_{2} \mathrm{D}_{3}$. Giving a high-Ca diet to adult non-lactating goats with low $\mathrm{Ca}$ requirements prior to the measurements resulted in a low initial rate of $\mathrm{Ca}$ absorption. This allowed observations of increments in absorption also at the lowest dose of $1,25(\mathrm{OH})_{2} \mathrm{D}_{3}$ used in the present study ( $1 \mu \mathrm{g}$ equivalent to $20-25 \mathrm{ng} / \mathrm{kg}$ body-weight). The fact that an increased rate of radiocalcium absorption was observed in the present study both 2 and $6 \mathrm{~d}$ after a single treatment with the $1 \mu \mathrm{g}$ dose of $1,25(\mathrm{OH})_{2} \mathrm{D}_{3}$ showed that this low dose was well above the threshold for stimulation of $\mathrm{Ca}$ absorption. Most trials in humans with exogenous $1,25(\mathrm{OH})_{2} \mathrm{D}_{3}$ have utilized doses of the metabolite comparable to the $1 \mu \mathrm{g}$ dose level in the present study. This dose is close to the estimated rate of $1,25(\mathrm{OH})_{2} \mathrm{D}_{3}$ production in normal man (140-680 ng/d; Mawer et al. 1976; Norman, 1979) and, on a body-weight basis, considered to be near physiological levels in the rat (Rizzoli et al. 1977; Bonjour et al. 1978; Lee et al. 1981). The sensitivity of intestinal $\mathrm{Ca}$ absorption in the goat to exogenous $1,25(\mathrm{OH})_{2} \mathrm{D}_{3}$ thus seems to be similar to the sensitivity found in both rat and man.

Increasing the dose of $1,25(\mathrm{OH})_{2} \mathrm{D}_{3}$ above the $1 \mu \mathrm{g}$ level resulted in gradually lower increments in $\mathrm{Ca}$ absorption, as emphasized by the logarithmic relationship between the dose of $1,25(\mathrm{OH})_{2} \mathrm{D}_{3}$ and the increments in Ca absorption (Fig. 3). An efficiency in $\mathrm{Ca}$ absorption of $40-50 \%$ is commonly thought to represent the maximum which can be 
achieved by dietary means in mature ruminants. Absorptions in this range were seen $2 \mathrm{~d}$ after administration of $5 \mu \mathrm{g} 1,25(\mathrm{OH})_{2} \mathrm{D}_{3}$, while the $25 \mu \mathrm{g}$ dose resulted in even higher values. Individual absorption values well above $70 \%$ were observed. Single doses of $1,25(\mathrm{OH})_{2} \mathrm{D}_{3}$ in the range of $5-25 \mu \mathrm{g}(100-500 \mathrm{ng} / \mathrm{kg}$ body-weight $)$ thus appeared to induce a near maximal stimulation of the intestinal Ca-transport system. The time during which the intestinal mucosal cells were exposed to increased concentrations of $1,25(\mathrm{OH})_{2} \mathrm{D}_{3}$ clearly influenced the adaptation in $\mathrm{Ca}$ absorption, as evidenced by the cumulative effect of repeated daily doses of $5 \mu \mathrm{g} 1,25(\mathrm{OH})_{2} \mathrm{D}_{3}$.

Plasma concentrations of $1,25(\mathrm{OH})_{2} \mathrm{D}_{3}$ varied according to the dose and the method of administration. Greatly elevated levels were seen after the $25 \mu \mathrm{g}$ dose, in accordance with the activated $\mathrm{Ca}$ absorption. Attention should be drawn to the fact that the concentrations of $1,25(\mathrm{OH})_{2} \mathrm{D}_{3}(200-500 \mathrm{pg} / \mathrm{ml}$ plasma) resulting from doses which gave rise to nearly maximal stimulation of $\mathrm{Ca}$ absorption, were in the same range as reported in cows with parturient hypocalcaemia (Horst et al. 1977). Plasma 1,25(OH) $\mathrm{D}_{3}$ concentrations were only measured once in the present study. From experiments with cows (Hove et al. 1983) it may be inferred that plasma $1,25(\mathrm{OH})_{2} \mathrm{D}_{3}$ concentrations in the present experiments would have returned to pretreatment levels 3-4 d after treatment. The persistence of stimulated $\mathrm{Ca}$ absorption beyond the 6th day after treatment may indicate that the biological action of $1,25(\mathrm{OH})_{2} \mathrm{D}_{3}$ is related to the life span of the epithelial cells of the intestinal mucosa. In agreement with recent results in the cow (Hove et al. 1983), plasma concentrations were two to five times higher after iv than after oral treatment (Table 1). Oral administration was, nevertheless, as effective in promoting $\mathrm{Ca}$ absorption as iv administration, except when $25 \mu \mathrm{g}$ was given unprotected. A logical explanation of these observations would be that the metabolite did expose the intestinal absorptive cells to high local concentrations at the time of absorption. This could in turn give rise to much higher rates of $\mathrm{Ca}$ absorption than those which would be expected from the ensuing plasma $1,25(\mathrm{OH})_{2} \mathrm{D}_{3}$ concentration. Some loss of $1,25(\mathrm{OH})_{2} \mathrm{D}_{3}$ was indicated especially at the $25 \mu \mathrm{g}$ dose level when the steroid was given unprotected orally, since the mean increment in $\mathrm{Ca}$ absorption was lower than after protected oral administration. This was, however, mainly due to the effects of different starting points, since mean values for $\mathrm{Ca}$ absorption $2 \mathrm{~d}$ after treatment were nearly identical (Fig. 2). It may be concluded that protection of cholecalciferol metabolites against rumen degradation is of limited value when $\mathrm{Ca}$ absorption is to be enhanced by oral treatment in ruminants.

A $10 \mu \mathrm{g}$ dose of $1(\mathrm{OH}) \mathrm{D}_{3}$ had a pronounced effect on radiocalcium absorption in the goats irrespective of the method of administration (Table 2). The fact that a $10 \mu \mathrm{g}$ dose of $1(\mathrm{OH}) \mathrm{D}_{3}$ gave increments in absorption equivalent to about $20 \mu \mathrm{g}$ of $1,25(\mathrm{OH})_{2} \mathrm{D}_{3}$ seems surprising since $1(\mathrm{OH}) \mathrm{D}_{3}$ is generally thought to be about half as active as $1,25(\mathrm{OH})_{2} \mathrm{D}_{3}$. The explanation may, however, be that the elimination of a clearly supraphysiological dose of $1,25(\mathrm{OH})_{2} \mathrm{D}_{3}$ occurs much more rapidly than elimination of the $1,25(\mathrm{OH})_{2} \mathrm{D}_{3}$ formed gradually from injected $1(\mathrm{OH}) \mathrm{D}_{3}$ as shown in the cow (Hove et al. 1983). Braithwaite (1978, 1980) observed maximal stimulation of $\mathrm{Ca}$ absorption in sheep already at a daily dose of $20 \mathrm{ng} / \mathrm{kg}$, which would be equivalent to the $1 \mu \mathrm{g}$ dose in the present study. The apparent discrepancy in sensitivity to $1(\mathrm{OH}) \mathrm{D}_{3}$ in the sheep and the goat can probably be explained by the pronounced cumulative effect of repeated doses of $1 \alpha$-hydroxylated cholecalciferol metabolities, since the sheep were treated for $10 \mathrm{~d}$ before measurements were completed.

The trihydroxylated metabolites used in the present study occur in very low concentrations relative to $1,25(\mathrm{OH})_{2} \mathrm{D}_{3}$ (Holick et al. 1973; Kleiner-Bossaler \& DeLuca, 1974; Reinhardt et al. 1981). The potency of $1,24(\mathrm{R}), 25(\mathrm{OH})_{3} \mathrm{D}_{3}$ and $1,25(\mathrm{~S}), 26(\mathrm{OH})_{3} \mathrm{D}_{3}$ was only about one-tenth to one-fifteenth of the potency of $1,25(\mathrm{OH})_{2} \mathrm{D}_{3}$ in stimulating $\mathrm{Ca}$ absorption in goats. In accordance with this finding, Hove et al. (1983) showed $1,25(\mathrm{OH})_{2} \mathrm{D}_{3}$ to be 
approximately ten times as effective as the two trihydroxylated metabolites in promoting hypercalcaemia in cows. Binding of $1,25(\mathrm{OH})_{2} \mathrm{D}_{3}$ to a specific receptor is recognized as a necessary step in the mediation of the metabolic effects of this hormone. Interestingly, the affinity of the two trihydroxylated compounds for intestinal cytosol receptors was about one-tenth the affinity of $1,25(\mathrm{OH})_{2} \mathrm{D}_{3}$ itself (Kream et al. 1977; Reinhardt et al. 1981).

It seems likely, therefore, that the stimulation of $\mathrm{Ca}$ absorption induced in the goats by the trihydroxylated metabolites was effected through the intestinal $1,25(\mathrm{OH})_{2} \mathrm{D}_{3}$ receptor. It cannot be ruled out, however, that changes in $1,25(\mathrm{OH})_{2} \mathrm{D}_{3}$ metabolism and plasma concentrations resulting from exogenous $1,24(\mathrm{R}), 25(\mathrm{OH})_{3} \mathrm{D}_{3}$ and $1,25(\mathrm{~S}), 26(\mathrm{OH})_{3} \mathrm{D}_{3}$ might influence calcium absorption (Horst et al. 1983). With the low activity of the two trihydroxylated metabolites any role in regulation of $\mathrm{Ca}$ absorption in the normal state can be ruled out.

Generous gifts of cholecalciferol metabolites from Hoffman la Roche and Leo Pharmaceuticals are acknowledged. The work was financed by a grant from the Norwegian Agricultural Research Council.

\section{REFERENCES}

Abdel-Hafeez, H. M., Manas-Almendros, M., Ross, R., Care, A. D. \& Marshall, D. H. (1982). British Journal of Nutrition 47, 69-77.

Aksnes, L. (1980). Clinica Chimica Acta 104, 133-146.

Bonjour, J. P., Rizzoli, R., Hugi, K., Haldimann, B. \& Fleisch, H. (1978). Metabolic Bone Disease and Related Research 1, 23-28.

Braithwaite, G. D. (1978). British Journal of Nutrition 40, 387-392.

Braithwaite, G. D. (1980). British Journal of Nutrition 44, 183-191.

Clemens, T. L., Hendy, G. N., Papapoulos, S. E., Fraher, L. J., Care, A. D. \& O'Riordan, J. L. H. (1979). Clinical Endocrinology 11, 225-234.

Holick, M. F., Kleiner-Bossaller, M. F., Schnoes, H. K., Kasten, P. M., Boyle, I. T. \& DeLuca, H. F. (1973). Journal of Biological Chemistry 248, 6691-6696.

Holick, M. F., Schnoes, H. K. \& DeLuca, H. F. (1971). Proceedings of the National Academy of Sciences USA 68, 803-804.

Horst, R. L., Eisman, J. A., Jorgensen, N. A. \& De Luca, H. F. (1977). Science 196, 662-663.

Horst, R. L., Hove, K., Littledike, E. T., Reinhardt, T. L., Uskokovic, M. R. \& Partridge, J. J. (1983). Journal of Dairy Science 66, 1455-1460.

Hove, K. (1984). British Journal of Nutrition 51, 145-156.

Hove, K., Horst, R. L. \& Littledike, E. T. (1983). Journal of Dairy Science 66, 59-66.

Hove, K. \& Kristiansen, T. (1982). Journal of Dairy Science 65, 1934-1940.

Kleiner-Bossaler, A. \& DeLuca, H. F. (1974). Biochemica et Biophysica Acta 338, 489-495.

Kream, B. A., Jose, M. J. L. \& DeLuca, H. F. (1977). Archives of Biochemistry and Biophysics 179, $462-468$.

Lee, D. B. N., Walling, M. M., Levine, B. S., Gafter, U., Silis, V., Hodsman, A. \& Coburn, J. W. (1981). American Journal of Physiology 240, G90-G96.

Mawer, E. B., Backhouse, J., Davies, M., Hill, L. F. \& Taylor, C. M. (1976). Lancet i, 1203.

Nicolaysen, R., Eeg-Larsen, N. \& Malm, O. J. (1953). Physiological Reviews 33, 424444.

Norman, A. W. (1979). Vitamin D. The Calcium Homeostatic Steroid Hormone. New York: Academic Press.

Norman, A. W., Myrtic, J. F., Midgett, R. J., Nowickz, H. G., Williams, W. \& Popjak, G. (1971). Science 173, 51-54.

Omdahl, J. L., Holick, M., Suda, T., Tanaka, Y. \& DeLuca, H. F. (1971). Biochemistry 10, $2935-2940$.

Reinhardt, T. A., Napoli, J. L., Pramanik, B., Littledike, E. T., Beitz, D. C., Partridge, J. J., Uskokovic, M. R. \& Horst, R. L. (1981). Biochemistry 20, 6230-6235.

Rizzoli, R., Fleisch, H. \& Bonjour, J. P. (1977). American Journal of Physiology 233, E 160-164.

Sommerfeldt, J. L., Horst, R. L., Napoli, J. L., Beitz, D. C. \& Littledike, E. T. (1980). Journal of Dairy Science 63 (Suppl. 1), 88-89. 